\author{
Vlatka Butorac Malnar, PhD, Assistant Professor \\ University of Rijeka, Faculty of Law \\ Hahlić 6, 51000, Rijeka, Croatia \\ vlatka@pravri.hr
}

Ivana Kunda, PhD, Associate Professor

University of Rijeka, Faculty of Law

Hahlić 6, 51000, Rijeka, Croatia

ikunda@pravri.hr

\title{
EU COMPETITION LAW IN THE DIGITAL ERA: WHAT TO TELL ABOUT INTEL?*
}

\begin{abstract}
Intel, a US-based company, was fined by the European Commission in 2009 for abusing its dominant position at the computer processor market intended to exclude its competitor AMD from that market. The penalty amounting to $€ 1.06$ bn was the largest antitrust fine in the Commission's history at the time. As the EU General Court had rejected Intel's appeal in 2014, the matter was brought before to EU Court of Justice. The CJEU judgment, rendered in September 2017, is controversial for at least two reasons. First is the territorial reach of the EU competition law outside the EU borders, and second relates to the treatment of exclusivity rebates. With regards to the former, for the first time the CJEU confirmed the position of the Commission and the General Court regarding the extended territorial reach of the EU antitrust legislation. Quite the opposite, the CJEU quashed the General Court ruling as to the former, arguably rejecting the traditional per se infringement of exclusivity rebates and embracing the effects-based analysis. The doctrine is somewhat divided as to whether this judgment is a much needed clarification of the two issues or it indicates a new direction in EU competition law analysis. This paper is addressing the most important ideas in the doctrinal interpretations and related arguments, and provides critical assessment of the present state of affairs. It also raises certain points relevant to the Intel judgment, which so far have not been given sufficient attention in the case comments and scholarship.
\end{abstract}

Keywords: Intel, CJEU, EU competition law

This paper was supported by the Croatian Science Foundation project no. 9366 "Legal Aspects of Corporate Acquisitions and Knowledge Driven Companies' Restructuring" 


\section{INTRODUCTION}

There is hardly another judgement of the Court of Justice of the EU $(\mathrm{CJEU})^{1}$ that sparked so much attention over the last couple of years as the one in Intel. ${ }^{2}$ This was a long awaited judgement for at least two reasons. For one thing, in its overturning quality this judgment is paving a way for the new direction of antitrust enforcement in respect of exclusive dealings and fidelity rebates. ${ }^{3}$ And for another, it is no less than a clear endorsement of the effects doctrine in determining the reach of the EU competition law beyond the EEA borders.

The newly accepted legal test for determining the outer reach of the EU competition law, which comes on top of the formerly established doctrine of "single economic unit" steaming from the Dyestuffs $s^{4}$ line of case law and "implementation" doctrine that emerged out of Wood Pulp, ${ }^{5}$ is one of the crucial issues in the judgment. At the centre of the judgment is also the principle that exclusive dealing and fidelity rebates under Article 102 of the Treaty on the functioning of the European Union ${ }^{6}$ (TFEU) must be treated as effect-based infringements. This approach departs from the traditional presumption of unlawfulness of such practices established by the CJEU in a sequence of cases starting with Suiker Unie in 1975 and Hoffmann la Roche $e^{8}$ in 1979. Legal scholarship is somewhat divided as to whether this judgment is a much needed clarification of the analytical framework of fidelity rebates or it indicates a new direction in EU competition law analysis.

1 In this paper, the name Court of Justice of the EU and the acronym CJEU are, for the purpose of simplicity, used regardless of whether the reference is made to the CJEU or the court under its pervious name, the European Court of Justice. The same is true when it comes to the General Court of the EU and its acronym GCEU, in relation to the previous name of the Court of First Instance

2 CJEU, judgment of 6 September 2017, Intel Corp. v European Commission, C-413/14 P, EU:C:2017:632

3 The term overturning is used to denote the de facto shift in approach taken by the CJEU, as CJEU does not abide by the doctrine of precedents and thus does not formally overturn its previous judgments. On that point see Petit, Nicolas, The Judgment of the EU Court of Justice in Intel and the Rule of Reason in Abuse of Dominance Cases (December 12, 2017), European Law Review, October 2018 (forthcoming), available at SSRN: [https://ssrn.com/abstract=3086402] or [http://dx.doi. org/10.2139/ssrn.308640219] Accessed 23.03.2018, p. 19

4 CJEU, judgment of 14 July 1972, Imperial Chemical Industries Ltd. $v$ Commission of the European Communities, Case 48-69, EU:C:1972:70

5 CJEU, judgment of 27 September 1988, Ahlström Osakeyhtiö and others v Commission of the European Communities and other, joined cases C-89/85, C-104/85, C-114/85, C-116/85, C-117/85 and C-125/85 to C-129/85, EU:C:1988:447

$6 \quad$ OJ C 326, 26.10.2012, pp. 47-390 (consolidated version)

7 CJEU, judgment of 16 December 1975, Coöperatieve Vereniging "Suiker Unie" UA and others $v$ Commission, C-40/73 etc., EU:C:1975:174

8 CJEU, judgment of 13 February 1979, Hoffmann-La Roche \& Co. AG $v$ Commission of the European Communities, C-85/76 EU:C:1979:36 
In order to understand the context of this judgement and its likely impact on future conduct, it is first necessary to briefly mention the facts of the case. This is followed by the chapter intended to provide insight into the essential criteria when it comes to defining the reach of EU primary competition law; while the next chapter is offering discussion on pros and cons of the new approach to exclusive dealing and fidelity rebates. Both chapters are structured in a way to contrast the previous developments to the CGEU and CJEU judgments in Intel.

\section{CASE BACKGROUND}

In 2009, the EU Commission found that Intel Corp., a US based chipset manufacturer, had abused its dominant position on the market for processors, in particular x86 CPUs, by implementing a strategy aimed at excluding its main competitor AMD from the market. Essentially, the Commission found that between 2002 and 2007 Intel engaged in two types of unlawful conduct - fidelity rebates and "naked restrictions". ${ }^{9}$ The former consisted of granting rebates to four original equipment manufacturers (Dell, Lenovo, HP and NEC) under the condition that they purchase all or almost all of their x86 CPUs from Intel. An important segment to the Commission's findings concerned the exclusivity rebates paid to two computer manufacturers (Acer and Lenovo) established in Asia, regarding a notebook computer for the domestic Taiwanese and Chinese markets, respectively. In addition, Intel granted payments to one trading partner, $\mathrm{MSH}$, under the condition that it sells exclusively computers containing Intel's x86 CPUs, which, according to the Commission, had the same economic mechanism as the described fidelity rebates. The second type of conduct, the "naked restrictions", consisted of payments that Intel made to several manufacturers so they would delay, restrict or cancel the marketing and distribution of Intel's competitor AMD's competing products.

The Commission found that because of Intel's conduct, competitors had a significantly diminished ability to compete, which harmed competition and resulted in reduction of consumer's choice. In addition, it found that each of these infringements was also a part of a single strategy aimed at excluding the only significant competitor from the market and thus found the existence of a single infringement of Article 102 of the TFEU. As a result, the Commission imposed on Intel a penalty amounting to $€ 1.06 \mathrm{bn}$, the largest antitrust fine in the Commission's history at the time.

9 Commission Decision C(2009) 3726 final of 13 May 2009 in case COMP/C-3/37.990 — Intel 
Following the unsuccessful action for annulment of the Commission decision before the General Court of the EU (GCEU), ${ }^{10}$ Intel brought an appeal against the GCEU judgement before the CJEU. It argued that the GCEU erred in law by failing to examine the rebates in light of all the relevant circumstances and assess the likelihood of a restriction to competition and by holding that the Commission had jurisdiction to apply Article 102 of the TFEU as regards the agreements concluded between Intel and Lenovo. ${ }^{11}$ While the CJEU quashed the GCEU judgement rejecting the applied traditional prima facie infringement of exclusivity rebates and embraced the effects-based analysis, it confirmed the reach of the EU competition law over the Intel's dealings with the Chinese company.

\section{TERRITORIAL SCOPE OF EU COMPETITION LAW}

\subsection{Pre-Intel case law}

Being one of the areas of law essential for preserving the sound economic organisation of the state, competition law has always been an expression of sovereign power. For the EU it is even more than that, it is foundation on which the ever closer union among Member States is built. Therefore, it is not surprising that confronted with the globalisation challenges, EU responds by defying territoriality and extending the scope of the competition law to persons and actions beyond its geographical borders. EU is certainly not alone in this as other big players on the global market show the same propensity. ${ }^{12}$ As discussed below, these players, US in particular, will strongly affect the EU position on the issue.

As a preliminary point it has to be noted, that the basic EU competition provisions, Articles 101 and 102 of the TFEU, have been interpreted not to restrict the territorial scope of competition law. ${ }^{13}$ In its 1964 decision in Grosfllex-Fillis-

10 GCEU, judgment of 12 June 2014, Intel Corp. v European Commission, T-286/09, EU:T:2014:547

11 CJEU, Intel, EU:C:2017:632, para. 31

12 The most prominent example is US. The central place belongs to the 1945 case United States v. Alcoa, 148 F.2d 416 (2d Cir. 1945), setting the precedent in favour extraterritorial application of competition law - the Sherman Act, on the bases of the "effects" doctrine. This inclination has continued to date with some adjustments and variances in the intensity owing to the political pressures from UK and some other US trading partners. During late 1970s and early 1980s, the notion of comity was temporary brought back into the equation, to lose its importance since the 1990s against the policy protecting US based companies against anti-competitive conduct abroad. Akbar, Y., The Extraterritorial Dimension of US and EU Competition Law: A Threat to the Multilateral System?, Australian Journal of International Affairs, 1999/53 (1), pp. 113-125, especially 115-119; Alford, R. P., The Extraterritorial Application of Antitrust Laws: The United States and European Community Approaches, Virginia Journal of International Law, 1992/33 (1), pp. 1-50, especially 6-27

13 CJEU judgment of 6 March 1974, Istituto Chemioterapico Italiano S.p.A. and Commercial Solvents Corporation $v$ Commission of the European Communities, joined cases 6 and 7-73., EU:C:1974:18, para 
torf, the Commission first asserted jurisdiction over a Swiss undertaking which together with French undertaking concluded an agreement to be performed in Switzerland, to determine that no action shall be taken as competition in the then common market was not restricted or distorted. ${ }^{14}$ The position that the relevant criterion for application of the EU competition law is the affected common market, regardless of the jurisdiction in which the undertaking involved in concerted practise is established, was repeated in the subsequent Commission decision in what is often referred to as Dyestuffs case or Aniline Dyes Cartel case. ${ }^{15}$ The Commission, and later on the CJEU deciding on the appeal, ${ }^{16}$ asserted jurisdiction over a parent company, whose registered office was in UK which at the time was not a Member State.

However, unlike the Commission, the CJEU in Dyestuffs did not overtly rely on the effects on the common market. Instead, the CJEU established the doctrine of a "single economic unit". It held that a parent company may be responsible for the conduct of its subsidiaries, in particular where the subsidiary, although having separate legal personality, does not decide independently upon its own conduct on the market, but carries out, in all material respects, the instructions given to it by the parent company. In view of the unity of the group thus formed, the actions of the subsidiaries may in certain circumstances, such as where the parent company holds all or majority of shares in subsidiary, be attributed to the parent company. ${ }^{17}$ Consequently, parent company's conduct amounting to "decisive influence" justifies exercise of EU legal jurisdiction. The doctrine of "single economic unit" served the CJEU for the purpose of avoiding explicit recognition of the effects doctrine, although essentially the broadening of the scope of application of EU competition law was all about the effects on the then common market. While the decision is based on "the unity of their conduct on the common market", ${ }^{18}$ in the opening of the argument on Commission's jurisdiction the CJEU states that it should be verified "whether the conduct of the applicant has had effects within the common market". ${ }^{19}$

31. Confirmed recently in GCEU, Intel, EU:T:2014:547, para. 248

14 64/233/CEE: Décision de la Commission, du 11 mars 1964, relative à une demande d'attestation négative présentée conformément à l'article 2 du règlement no 17 du Conseil (IV/A-00061 - Grosfillex-Fillistorf), OJ 58, 9.4.1964, pp. 915-916

15 69/243/CEE: Décision de la Commission, du 24 juillet 1969, relative à une procédure au titre de l'article 85 du traité C.E.E. (IV/26.267 - Matières colorantes), OJ L 195, 7.8.1969, pp.11-17

16 CJEU, judgment of 14 July 1972, Imperial Chemical Industries Ltd. $v$ Commission of the European Communities, case 48-69, EU:C:1972:70. See also CJEU, judgment of 21 February 1973, Europemballage Corporation and Continental Can Company Inc. $v$ Commission of the European Communities, case 6-72, EU:C:1973:22

17 CJEU, Imperial Chemical Industries - Dyestuffs, EU:C:1972:70, paras. 132-136

18 CJEU, Imperial Chemical Industries - Dyestuffs, EU:C:1972:70, paras. 140

19 CJEU, Imperial Chemical Industries - Dyestuffs, EU:C:1972:70, paras. 126 
The weakness of the "single economic entity" doctrine soon became evident when the participants in the concerted practices were all established outside the common market: Without a subsidiary in the EU territory, a foreign-based company cannot be captured under Article 101 of the TFEU. In Wood Pulp ${ }^{20}$ the single link to the EU territory was sale of the products into the EU market. Again, the CJEU was not prepared to embark on the "effects doctrine" but looked for an alternative way to justify the EU jurisdiction. The reason was probably the political position in EU, especially in UK, against the "effects doctrine" in the US, ${ }^{21}$ to which legal scholars provided scientific support by labelling it contrary to the principle of the sovereignty of States. ${ }^{22}$ The CJEU reasoned that an infringement of Article 101 of the TFEU, such as the conduct of a horizontal agreement with the aim of exchanging price information which has the effect of restricting competition within the EU market, consists of conduct made up of two elements: the "formation" of the agreement, decision or concerted practice and the "implementation" thereof. The CJEU went on to say that if the applicability of prohibitions laid down under competition law are to depend on the place where the agreement, decision or concerted practice is formed, the result would obviously be to give undertakings an easy means of evading those prohibitions. Whether the producers use subsidiaries, agents, sub-agents, or branches inside the EU as under the doctrine of the "single economic unity", or act directly on the EU market makes no difference for the application of the EU law. It is the place where the prohibited concerted practice is implemented that is relevant for application of EU competition rules. Such party's conduct is covered by the territoriality principle as universally recognized in public international law. ${ }^{23}$

The reception of the "implementation" doctrine was evident in both the European Commission and the GCEU practice. A year later, Commission relied on the judgment in Wood Pulp when issuing decisions against foreign companies. ${ }^{24}$

20 CJEU, Ahlström, EU:C:1988:447

21 Gradine, D., Reyesen, M., Henry, D., Extraterritoriality, Comity and Cooperation in EU Competition Law, in: Guzmán, A. T. (ed.), Cooperation, Comity, and Competition Policy, Oxford University Press, 2011, pp. 21-44, 26; Braakman, A. J., Brexit and its Consequences For Containerised Liner Shipping Services, The Journal of International Maritime Law, 2017/23 (4), pp. 254-265, 257; Cannon, R., Laker Airways and the Courts: A New Method of Blocking the Extraterritorial Application of U. S. Antitrust Laws, Journal of Comparative Business and Capital Market Law, 1985/7, pp. 63-87

22 See e.g. Robertson, A., Demetriou, M., "But that was another country...": The Extra-Territorial Application of the US Antitrust Laws in the US Supreme Court, International and Comparative Law Quarterly, 1994/43, pp. 417-425

23 CJEU, Ahlström Osakeyhtiö, EU:C:1988:447, paras. 16-18

24 89/190/EEC: Commission Decision of 21 December 1988 relating to a proceeding pursuant to Article 85 of the EEC Treaty (IV/31.865, PVC), OJ L 74, 17.3.1989, p. 1-20: the Commission stated: "The fact that Norsk Hydro had its main business centres and production facilities outside the Com- 
A decade later, the GCEU applied it in Gencor. ${ }^{25}$ This was a case involving Gencor, a company incorporated under South African law, and Lonrho, a company incorporated under English law, both operating in mining and metals sectors. They proposed concentration between the South-African interests in subsidiary companies: to acquire joint control of Implats, where Gencor held 46.5\%, and then to grant Implats sole control of Eastplats and Westplats, where Lonrho held $73 \%$ and Gencor 27\%. Whereas the South African competition authority did not oppose the concentration under its competition law, the Commission was of the opposite opinion. According to the Commission, if that transition was carried out Implats would have acquired sole control of Eastplats and Westplats, eliminating competition between those two undertakings, not only in platinum group metals sector in South Africa but also in the EU where Implats, Eastplats and Westplats achieved significant sales. Actually, it would have led to a collective dominant position in the world platinum and rhodium market on the part of the entity arising from the concentration and Amplats, the leading supplier worldwide. Gencor went for the annulment of the Commission decision contending in particular that the Merger Regulation ${ }^{26}$ sanctioned only mergers carried out within the EU. The CGEU pointed out that the Regulation applies to all concentrations with a "Community dimension" and that it does not require that either the undertakings in question must be established in the EU or that the production activities covered by the concentration must be carried out within EU territory. ${ }^{27}$

munity does not affect its liability in respect of any agreement implemented within the Community. The Community is a primary market for Norsk Hydro and accounts for some $60 \%$ of its turnover in PVC. [...] In so far as the agreements were implemented inside the Community, the applicability of Article 85 (1) of the EEC Treaty to a Norwegian producer is not precluded by the free trade agreement between the European Economic Community and Norway"; 89/191/EEC: Commission Decision of 21 December 1988 relating to a proceeding pursuant to Article 85 of the EEC Treaty (IV/31.866, LdPE), OJ L 74, 17.3.1989, p. 21-44: The Commission stated: "Dow is a United-States-owned company but is one of the largest LdPE undertakings operating in the Community and its European LdPE production facilities are located in the Netherlands and in Spain. The fact that Chemie Holding, Neste Oy and Statoil have their LdPE production as well as their main business centres outside the Community does not affect their liability in respect of any agreement implemented within the Community. [...] In so far as the agreements were implemented inside the Community, the applicability of Article 85 (1) of the EEC Treaty to the Austrian, Finnish and Norwegian producers is not precluded by the free trade agreements between the European Economic Community on the one hand and Austria, Finland and Norway on the other"

25 CGEU, judgment of the of 25 March 1999, Gencor Ltd $v$ Commission of the European Communities, T-102/96, EU:T:1999:65

26 The Council Regulation (EEC) No 4064/89 of 21 December 1989 on the control of concentrations between undertakings, OJ L 395, 30.12.1989, p. 1-12, was invoked in the case. This Regulation is no longer in force as it was repealed and replaced by the Council Regulation (EC) No 139/2004 of 20 January 2004 on the control of concentrations between undertakings (the EC Merger Regulation), OJ L 24, 29.1.2004, pp. 1-22

27 CGEU, Gencor, EU:T:1999:65, para. 79 
The CGEU declared itself about the "implementation" doctrine, which Gencor invoked to support its interpretation of the restricted territorial scope of the Regulation. However, the GCEU held that criterion for assessing the link between an agreement and EU territory in fact precludes such narrow interpretation. According to the judgment in Wood Pulp, the criterion as to the implementation of an agreement is satisfied by mere sale within the EU, irrespective of the location of the sources of supply and the production plant. The CFI further held that Gencor was captured by the EU competition law on the non-disputed fact that Gencor and Lonrho carried out sales in the EU before the concentration and would have had continued to do so thereafter. ${ }^{28}$ Thus, EU competition authorities have jurisdiction in a situation where a foreign undertaking sells its products directly to purchasers in EU. But the GCEU went further by stating that in addition to certain volume of sales in EU, the Merger Regulation in Gencor is justified as a matter of public international law because "the three criteria of immediate, substantial and foreseeable effect [in the EC] are satisfied in this case". ${ }^{29}$

Regardless of this and other references to the "effects" doctrine, such as by the European Commission ${ }^{30}$ and Advocate Generals, ${ }^{31}$ at the time of the Gencor judgment the "implementation" doctrine was still sufficient. Thus, the rule at the time was that the location where an agreement, decision or a concerted practice is formed does not play a role, while the decisive element was the implementation within the EU. ${ }^{32}$ It has been noted in the scholarship that reasonableness of the reasoning depends on whether both, the "formation" of the restraint of competition and the "implementation" of the restraint of competition, make part of the

CGEU, Gencor, EU:T:1999:65, para. 87

CGEU, Gencor, EU:T:1999:65, para. 92 along with 90-111

64/233/CEE: Décision de la Commission, du 11 mars 1964, relative à une demande d'attestation négative présentée conformément à l'article 2 du règlement no 17 du Conseil (IV/A-00061 - Grosfillex-Fillistorf), OJ 58, 9.4.1964, pp. 915-916; 2006/897/EC: Commission Decision of 19 January 2005 relating to a proceeding under Article 81 of the EC Treaty and Article 53 of the EEA Agreement against Akzo Nobel NV and others, OJ L 353, 13.12.2006, p. 12-15. See further references in Wagner-von Papp, F., Competition Law in EU Free Trade Cooperation Agreements (and What the UK Can Expect After Brexit), in: Bungenberg, M., et al. (eds.), European Yearbook of International Economic Law, Springer, 2017, pp. 301-360, 311, n. 35. See also Working Party No. 3 on Co-operation and Enforcement, Roundtable on cartel jurisdiction issues, including the effects doctrine, 21.10.2008, p. 4. available at [http://ec.europa.eu/competition/international/multilateral/oecd_submissions.html] Accessed 23.03.2018

31 Opinion of Advocate General Mayras of 2 May 1972, Imperial Chemical Industries Ltd. v Commission of the European Communities, joined cases 48-69 - 57-69, EU:C:1972:32, section II.A et seq.; Opinion of Advocate General Damon of 7 June 1992, joined cases C-89/85, Ahlström Osakeyhtiö et al. V. Commission, EU:C:1988:258, para. 4 et seq.

32 Frenz, W., Handbook of EU Competition Law, Springer, 2016, p. 135; Katzorowska, A., European Union Law, Routledge, 2013, p. 780 
conduct prohibited by EU competition rules. As such it amounts to objective territoriality principle which covers conduct originating abroad but completed within the territory of the State (or EU, as in this case) applying its law. ${ }^{33}$

However, just like the doctrine of a "single economic unit", the "implementation" doctrine soon revealed its practical limitations. Under these doctrines combined, EU competition law operates with a requirement that there be an adequate link to the EU territory, be it in the form of the presence of a subsidiary, or the implementation of anticompetitive conduct within that territory. However, when comparing the EU "implementation" doctrine and the US "effects" doctrine, the noted divergence arises out of the fact that under the former the EU law would not apply to a situation where an agreement entered into outside the EU prohibits sales within the EU or purchases from EU producers, whereas under the latter the US competition law would be applicable provided that such an agreement is directed at the US market. ${ }^{34}$ This proved to be true in Intel where the CJEU eventually ceased avoiding the "effects" doctrine.

\subsection{The CGEU judgment}

Deciding on the challenge against the European Commission decision in Intel, ${ }^{35}$ the CGEU had to decide, not only on the substantive issues dealt with in chapter 4 of this paper, but also on the EU jurisdiction. Intel's plea was limited solely to the conduct vis-à-vis Acer and Lenovo. Intel argued that manufacturing facilities of the two companies were outside the EU, and that they did not purchase the processors in the EEA from Intel or AMD, but that the conduct at issue concerned sales of processors to customers in Asia, namely in Taiwan as regards Acer and in China as regards Lenovo, and that conduct was implemented in Asia. Intel claimed that the fact that a certain number of Acer and Lenovo computers might subsequently have been sold within EU is irrelevant to the question of the implementation of the allegedly illegal conduct. The effects of Intel's conduct would be felt in Asia, not EU, while only the sales of computers in EU was carried out by third parties, Acer and Lenovo, which were not controlled by Intel. Intel also

\footnotetext{
33 Behrens, P., The extraterritorial reach of EU competition law revisited - The "effects doctrine" before the ECJ, Discussion paper 3/2016, Europa-Kolleg Hamburg Institute for European Integration, 2016, [https://www.econstor.eu/bitstream/10419/148068/1/87238506X.pdf_Accessed 23.03.2018, p. 11

34 Griffin, J., Foreign Governmental Reactions to US Assertions of Extraterritorial Jurisdiction, George Mason Law Review, 1998/6 (3), pp. 505-524. See also Whish, R., Bailey, D., Competition Law, 7th ed., Oxford University Press, 2012, p. 467.; Opinion of the Advocate General Wahl of 20 October 2016, Intel Corp. v European Commission, C-413/14 P, EU:C:2016:788, para. 294

35 GCEU, Intel, EU:T:2014:547
} 
claimed that the volume of computers concerned was very small do that if there were any effects at all in EU, it would not have been substantial. ${ }^{36}$

The GCEU stated that the CJEU and GCEU case law follow two approaches in order to establish that the Commission's jurisdiction is justified under the rules of public international law: the "implementation" doctrine and the "qualified effects" doctrine, which apply as the alternative grounds. ${ }^{37}$ In applying the "implementation" doctrine to the case at hand, the GCEU stated it is not necessary to examine whether there were any effects in order to establish jurisdiction, but only existence of a dominant position within the common market or in a substantial part of it and that trade between Member States was capable of being affected. ${ }^{38}$

To satisfy the requirements of substantial, direct and foreseeable effects in the EU, it is not necessary to prove that the actual effects have taken place, it suffices that a threat to the effective competition structure in the common market is demonstrated, which did not materialize or has not yet materialized. Otherwise, the Commission's task to ensure that competition within the internal market is functioning would not be fully attainable. ${ }^{39}$ This GCEU's holding was followed by testing each of the prohibited conduct against the three qualifiers (foreseeability, directness and substantiality ${ }^{40}$ ), with the positive result justifying the Commission jurisdiction in this case ${ }^{41}$ This a highly fact-sensitive analysis which is discussed in the next section. ${ }^{42}$

\subsection{The CJEU judgment}

The GCEU judgment was appealed before the last instance - the CJEU. While the CJEU found that the GCEU should have addressed Intel's arguments about

36 GCEU, Intel, EU:T:2014:547, paras. 225-228

37 GCEU, Intel, EU:T:2014:547, para. 244

38 GCEU, Intel, EU:T:2014:547, para. 247, and corresponding arguments in paras. 301-320. See also Cardoso Pereira, J., Intel and the Abuse of Dominant Position: the General Court Upholds the Highest Fine Imposed on a Single Company for a Competition Law Infringement, European Law Reporter, 2017/7-8, pp. 204-209, especially, 207

39 GCEU, Intel, EU:T:2014:547, paras. 250-252

40 The effects test, including the three qualifiers, has been made part of the recent legislation pertinent to financial market sector. See, e.g. Article 28(2) of the Regulation (EU) No 600/2014 of the European Parliament and of the Council of 15 May 2014 on markets in financial instruments and amending Regulation (EU) No 648/2012, OJ L 173, 12.6.2014, p. 84-148, and Article 4(1)(a)(v) and 11(12) of the Regulation (EU) No 648/2012 of the European Parliament and of the Council of 4 July 2012 on OTC derivatives, central counterparties and trade repositories, OJ L 201, 27.7.2012, p. 1-59. See more, Joanne. Scott, The new EU “extraterritoriality”, Common Market Law Review, 2014/ 51(5), pp. 1343-1380, especially 1356-1359

41 GCEU, Intel, EU:T:2014:547, paras. 259-282

${ }^{42} \quad$ See section 3.3 
the economic impact of its conduct as discussed below, ${ }^{43}$ Intel's arguments on the Commission's territorial jurisdiction and scope of EU law were rejected. Intel argued in its appeal that Commission has no jurisdiction to apply EU competition law in respect of agreements entered into with Lenovo.

The part of the CJEU judgment regarding the jurisdiction confirms the GCEU position that the "qualified effects test" is a self-sufficient base for establishing territorial jurisdiction, ${ }^{44}$ and not a simple corollary to the "implementation test" as was suggested due to ambiguity in the Gencor judgment. It explains that both doctrines pursue the objective of preventing conduct, which, while not adopted within the EU, has anticompetitive effects liable to have an impact on the EU market. As such, these tests derive from Articles 101 and 102 of the TFEU. ${ }^{45}$ Intel argued that the GCEU erred in establishing that the 2006 and 2007 agreements with Lenovo concerning processors for delivery in China would have qualified effects in the EU.

In response, the CJEU for the first time affirmed the position of the Commission and the GCEU that, under the "qualified effects test", the application of EU competition law is consistent with public international law provided it is foreseeable that the conduct in question has an immediate and substantial effect on the EU internal market. To satisfy the requirement of foreseeability of effects, the CJEU explained that it is sufficient to consider the probable effects of the conduct on competition. The CJEU further agreed with the GC that Intel's conduct vis-à-vis Lenovo formed part of an overall strategy aimed at foreclosing AMD's access to the most important sales channels. It was determined that Intel's intent from the agreement with Lenovo was to impede any Lenovo notebook equipped with an AMD processor from being marketed anywhere, including on the internal market. As such, Intel's conduct was capable of producing an immediate effect on the EU. ${ }^{46}$ In carrying on this analysis, in particular the substantial nature of effects on the market, the CJEU emphasised the need to consider the company' conduct in question as a whole. Otherwise, one risks that the conduct is artificially fragmented into a number of separate forms of conduct and, consequently, prone to escape EU law and affect construction of the internal market. ${ }^{47}$

This was the first time that the CJEU expressly relied on the "qualified effects" doctrine justifying the application of EU competition law to foreign companies

\footnotetext{
43 See section 4.4

${ }_{44}$ CJEU, Intel, EU:C:2017:632, para. 240

45 CJEU, Intel, EU:C:2017:632, paras. 42 and 45

46 CJEU, Intel, EU:C:2017:632, paras. 48-52

47 CJEU, Intel, EU:C:2017:632, paras. 54-57
} 
concluding agreements abroad to be implemented abroad, but with effects on the EU market. Recognition of the "qualified effects" doctrine was probably due to the existing global state of affairs when it comes to acknowledging the need to control huge players on the global market, which in the absence of global supervision has to take place on a national or regional level. US approach, once politically intolerable to EU, became acceptable to it. This caused the positions in international public law to take the "new orientation" more permissive of what some term as "extraterritoriality" in competition law. ${ }^{48}$ In practical terms this does not mark a completely new era in application of EU competition law because large amount of cases are already falling within the formerly established doctrine of "single economic unit" and in particular the "implementation" doctrine. Merely cases concerned with negative conducts, such as prohibiting sales within the EU or purchases from EU producers will necessitate the operation of the "qualified effects" doctrine. Having said that, acceptance of "qualified effects" doctrine is still an important development in EU competition law in a view of increasing global conduct with potential effects in the internal market. This is particularly true if one takes into account the current Commission cases concerning Qualcomm ${ }^{49}$ and Google ${ }^{50}$.

\section{EXCLUSIVE DEALING AND FIDELITY REBATES}

\subsection{Pre-Intel case law}

Article 102 of the TFEU prohibits the abuse of dominant position within the internal market or a substantial part of it, inasmuch as it affects trade between Member States. In order to find the abuse of dominant position, the conduct in question must produce anticompetitive effects on the relevant market. This criterion is not detailed in Article 102 of the TFEU, rather it originates from the CJEU case law where the main issue was the standard of anticompetitive effects amounting to abuse of dominance and the related standard of proof. The CJEU held that detriment to competition does not have to be actual; ${ }^{51}$ however, it neither suffices

48 Basedow, J., Competition policy in a globalized economy: from extraterritorial application to harmonization, in: Neumann, M., Weigand, J. (eds.), The International Handbook of Competition, Edward Elgar, 2004, pp. 321-338, 323

49 See details of the case before the Commission at 'http://ec.europa.eu/competition/elojade/isef/case_details.cfm?proc_code=1_40220] Accessed 23.03.2018

50 See details of the two cases before the Commission at http://ec.europa.eu/competition/elojade/isef/case_details.cfm?proc_code=1_40411] (AdSense) and [http://ec.europa.eu/competition/elojade/isef/case_details.cfm?proc_code=1_40099] (Alphabet) Accessed 23.03.2018

51 CJEU, judgment of 15 March 2007, British Airways plc v Commission of the European Communities, C-95/04 P EU:C:2007:166, para. 145: The CJEU stated that "there is nothing to prevent discrimina- 
for it to be only hypothetical. ${ }^{52}$ Within this span, the CJEU developed a nuanced approach to this issue, depending on the type of conduct in question, differentiating between, what have been termed as "rule-based" and "effects-based" abuses. ${ }^{53}$ The divide is very important in practice as it entails a different approach to the evidentiary burden and standard of proof, the standard of anticompetitive effects and its significance. ${ }^{54}$

In 1979, in the seminal case Hoffman la Roche, ${ }^{55}$ the CJEU held that fidelity rebates granted by dominant undertakings are subject to rule-based presumption of illegality because they are "designed to deprive the purchaser of or restrict his possible choices of sources of supply and to deny other producers access to the market". ${ }^{6}$ According to the CJEU, this assumption extended to all practices of dominant undertakings that tie purchasers "by an obligation or promise on their part to obtain all or most of their requirements exclusively from the said undertaking". ${ }^{57}$

tion between business partners who are in a relationship of competition from being regarded as being abusive as soon as the behaviour of the undertaking in a dominant position tends, having regard to the whole of the circumstances of the case, to lead to a distortion of competition between those business partners. In such a situation, it cannot be required in addition that proof be adduced of an actual quantifiable deterioration in the competitive position of the business partners taken individually."

52 CJEU, judgment of 6 October 2015, Post Danmark A/S v Konkurrenceradet. (Post Danmark II), C-23/14 EU:C:2015:651 paras. 65-67.: "[T]he anticompetitive effect of a particular practice must not be of purely hypothetical. In that regard, [...], the anticompetitive effect of a particular practice must not be of purely hypothetical. The Court has also held that, in order to establish whether such a practice is abusive, that practice must have an anticompetitive effect on the market, but the effect does not necessarily have to be concrete, and it is sufficient to demonstrate that there is an anticompetitive effect which may potentially exclude competitors who are at least as efficient as the dominant undertaking (judgment in TeliaSonera Sverige, C-52/09, EU:C:2011:83, para. 64). It follows that only dominant undertakings whose conduct is likely to have an anticompetitive effect on the market fall within the scope of Article 82 EC."

53 Commentators of Article 102 do not use consistent terminology to differentiate between the two categories of abuses. Most terminological differences relate to the first category of abuses. Some refer to them per se abuses, quasi per se abuses, prima facie abuses, abuses by object, or rule-based abuses. This differentiation in terminology is not accidental; each of the terms indicates a different understanding of what actually is the underlying requisite legal standard developed in EU Courts case law. While all agree that this type of abuse rests on the presumption of illegality, some disagree that such presumption is in effect rebuttable, thus they often refer to this type of abuses as per se abuses. See more in this article in the text accompanying note 65

54 See Kadar, M., The meaning of "Anticompetitive Effects" Under Article 102 TFEU, CPI Antitrust Chronicle, March 2016(1), available at:

'https://www.competitionpolicyinternational.com/wp-content/uploads/2016/03/The-Meaning-of-Anticompetitive-Effects.pdf] Accessed 23.03.2018

55 CJEU, Hoffmann-La Roche, EU:C:1979:36

56 CJEU, Hoffmann-La Roche, EU:C:1979:36, para. 90

57 CJEU, Hoffmann-La Roche, EU:C:1979:36, para. 89: The CJEU also held that this included tying at purchasers' request and regardless of whether the obligation in question is stipulated without further qualification or whether it is undertaken in consideration of the grant of a rebate 
This rule applied irrespective of the quantity of purchases, a long-term contractual relationship between the dominant undertaking and the purchaser, or the request of the purchasers to grant rebates or a unilateral decision by the dominant undertaking to do so. ${ }^{58}$ Under this traditional approach, the presumption of illegality may be rebutted by showing that the conduct in question is "objectively necessary or that the exclusionary effect produced may be counterbalanced, outweighed even, by advantages in terms of efficiency that also benefit consumers." ${ }^{59}$ This essentially means that, absent an objective justification, any type of exclusive dealing and fidelity rebates would have been found illegal because they were considered to be capable of restricting competition by their very nature, and thus it was not necessary to establish actual or potential anticompetitive effects on a case-by-case basis. ${ }^{60}$ With these kinds of abuses, it is up to the dominant undertaking to rebut the presumption of illegality by demonstrating the existence of an objective justification.

Unlike the described rule-based abuses of dominant position, there are a number of other practices on the market that may be found abusive only insofar as the Commission proves, based on an effects-based analysis, that the actual conduct is likely to produce exclusionary effects on the market. An example of this type of conduct would be various pricing practices, such as margin squeeze, as confirmed by the CJEU in Deutsche Telecom, ${ }^{61}$ TeliaSonera ${ }^{62}$ and more recently Telefónica de Espana. ${ }^{63}$ Under this approach, the CJEU requires the Commission to take into account all particulars of the case, and demonstrate the likelihood of negative effects on the market. Here the burden of proof rests with the Commission to demonstrate that the conduct in question is likely to produce anticompetitive effects.

The idea that some conducts by dominant undertakings are presumably unlawful while others are considered unlawful only insofar as they are likely to have anti-

58 CJEU, Hoffmann-La Roche, EU:C:1979:36, para 89

59 CJEU, judgment of 27 March 2012, Post Danmark A/S v Konkurrenceradet (Post Danmark I), C-209/10., EU:C:2012:172, para. 41

60 GCEU, Intel, EU:T:2014:547, paras. 71 and 143

${ }_{61}$ CJEU, judgment of 14 October 2010, Deutsche Telekom AG v European Commission, C-280/08 P, EU:C:2010:603

62 CJEU, judgment of 17 February 2011, Konkurrensverket v TeliaSonera Sverige AB, C-52/09, EU:C:2011:83

63 CJEU, judgment of 10 July 2014, Telefónica SA and Telefónica de España SAU v European Commission, C-295/12 P, EU:C:2014:2062. Citing the TeliaSonera judgement, in para. 124, the CJEU held: "In order to establish that a practice such as margin squeeze is abusive, that practice must have an anti-competitive effect on the market, although the effect does not necessarily have to be concrete, it being sufficient to demonstrate that there is a potential anti-competitive effect which may exclude competitors who are at least as efficient as the dominant undertaking." 
competitive effects is comparable to the divide between infringements by object or effect under Article 101 of the TFEU. ${ }^{64}$ Unlike Article 102, Article 101 expressly provides that agreements between undertakings are prohibited if they have as "object or effect" the prevention, restriction or distortion of competition. It is a settled case law under Article 101 that agreements which are anticompetitive by object do not necessitate an analysis of actual of potential effects on competition. The rationale behind it is that restrictions by object are presumed to have anticompetitive effects. Although not normatively expressed, this same underlying principle is at the heart of Article 102 as demonstrated by the CJEU case law. However, there is as a view expressed that under prima facie illegality of fidelity rebates, objective justification cannot be used to rebut the presumption of illegality as it already assumes that the restriction exists. ${ }^{65}$ Often such infringements are thus referred to as per se infringements, which, according to some commentators are unjustifiably equated with the treatment of cartels under Article 101. ${ }^{66}$

\subsection{Adoption of the Guidance paper}

The rule-based approach to abuses of dominant position has been criticized heavily over the years, on other grounds as well. Most of the criticism pointed out that such a formalistic approach to abuse of dominance does not correspond to economic findings indicating that there are many occasions in which such practices in fact do not restrict competition through foreclosure, and thus should not be treated as prima facie abuses. ${ }^{67}$ The proponents of this view insisted on an effects-

${ }_{64}$ For a more detailed discussion on infringements by object versus infringements by effect see Ibáñez Colomo, P., Editorial: The divide between restrictions by object and effect: why we discuss it and why it matters, Competition Law Review 2016/1 (2), pp. 173-180, especially p. 174. See also Ibánez Colomo, P., Intel and Article 102 TFEU Case Law: Making Sense of a Perpetual Controversy (November 26, 2014), LSE Legal Studies Working Paper No. 29/2014, available at SSRN:

https://ssrn.com/abstract=2530878] or [http://dx.doi.org/10.2139/ssrn.2530878] Accessed 23.03.2018

65 See Lamadrid, A., More questions (and some answers) on, and beyond, Intel (C-413/14P), 6 September 2017, available at:

https://chillingcompetition.com/2017/09/06/more-questions-and-some-answers-on-and-beyond-intel-c-41314-p/] Accessed 23.03.2018

66 Ibáñez Colomo, Intel and Article 102 TFEU... op. cit. note 64, p. 174; Ibáñez Colomo, P., More on Intel: some thoughts after the IBA Conference in Florence, 12 September 2017, available at:

https://chillingcompetition.com/2017/09/12/more-on-intel-some-thoughts-after-the-iba-conference-in-florence/] Accessed 23.03.2018; Geradin, D., Loyalty Rebates after Intel: Time for the European Court of Justice to Overrule Hoffman-La Roche, Journal of Competition Law \& Economics, 2015/11 (3), pp. 579-615

67 See Ibáńez Colomo, Intel and Article 102 TFEU..., op. cit. note 64, p. 19-20 and accompanying note 78; Geradin, ibid. page 580 and accompanying note 5 
based approach to exclusionary practices in general, including fidelity rebates. ${ }^{68} \mathrm{In}$ 2005, with a view of modernising enforcement under Article 102 of the TFEU, the Commission published a Staff Discussion paper on the application of EC Treaty competition rules on the abuse of a dominant market position, ${ }^{69}$ provoking a long and heated public debate,$^{70}$ which resulted in the adoption of the Guidance paper to exclusionary abuses of dominance ${ }^{71}$ (Guidance paper) in 2009.

While recognising that there may be instances in which a conduct is anticompetitive by its nature, as it can only raise obstacles to competition and create no efficiencies, the Guidance paper generally embraces new economic findings, departing from the CJEU traditional case law on rule-based abuses of dominant position. ${ }^{72}$ According to the Guidance paper, the Commission should intervene under Article 102 only where the conduct is likely to lead to anticompetitive foreclosure ${ }^{73}$ having negative impact on consumer welfare. In order to determine whether this is the case, the Commission is to take into account a number of qualitative and quantitative criteria of assessment such as the position of the dominant undertaking, the conditions on the relevant market, the position of the dominant undertaking's competitors, the position of costumers or input supplies, the extent of the allegedly abusive conduct, possible evidence of foreclosure, and direct evidence of exclusionary strategy. ${ }^{74}$ Particularly helpful in that regard should be the applica-

68 See Report by the EAGCP, An economic approach to Article 82, July 2005

[http://ec.europa.eu/dgs/competition/economist/eagcp_july_21_05.pdf] Accessed 23.03.2018, arguing in favour of an economic based approach to Article 102 of the TFEU as opposed to form-based approach to competition policy

69 DG Competition discussion paper on the application of Article 82 of the Treaty to exclusionary abuses, Brussels, December 2005, http://ec.europa.eu/competition/antitrust/art82/discpaper2005.pdf] Accessed 23.03.2018

70 Comments on the public consultation on discussion paper on the application of Article 82 to exclusionary abuses (March 2006), http://ec.europa.eu/competition/antitrust/art82/contributions.html] Accessed 23.03.2018

71 Communication from the Commission - Guidance on the Commission's enforcement priorities in applying Article 82 of the EC Treaty to abusive exclusionary conduct by dominant undertakings, OJ C 45, 24.2.2009, pp. 7-20

72 In point 22 of the Guidance paper, the Commission concedes by stating that where certain conduct can only raise obstacles to competition and creates no efficiencies, its anticompetitive effect may be inferred. However, this type of approach is not rule, and it does not apply to conditional rebates

73 According to point 19 of the Guidance paper, "term 'anti-competitive foreclosure' is used to describe a situation where effective access of actual or potential competitors to supplies or markets is hampered or eliminated as a result of the conduct of the dominant undertaking whereby the dominant undertaking is likely to be in a position to profitably increase prices to the detriment of consumers. The identification of likely consumer harm can rely on qualitative and, where possible and appropriate, quantitative evidence. The Commission will address such anti-competitive foreclosure either at the intermediate level or at the level of final consumers, or at both levels."

74 Point 20 of the Guidance paper 
tion of the "as efficient competitor test" (AEC test), ${ }^{75}$ which will later on find its way into the CJEU judgment in Intel.

The AEC test consists of a detailed cost analysis based on the comparison of product prices and costs of its production, which enables estimation of the effective price that a competitor would have to offer for the contestable portion of demand in order to compensate the buyers for the loss of conditional rebate. ${ }^{76}$ As a measure of the effective price level of competitors' products, the Commission uses the costbased analysis rooted in long run (average) incremental costs (LRIC) and average avoidable cost (AAC)..$^{77}$ Generally, the lower the effective price that a competitor has to offer compared to the average price of the dominant undertaking, the greater the fidelity-inducing effect. ${ }^{78}$ Abuse is measured against an equally efficient competitor and not actual or potential competitors that may be less efficient. ${ }^{79}$ The dominant undertaking thus becomes a cost benchmark for a hypothetical, equally efficient competitor. ${ }^{80}$

At the time the Guidance paper was adopted a large gap was created between the new analytical framework suggested by the Commission on one side, and the traditional analytical framework applied by the EU Courts on the other. The gap has been pointed to many times over the years as the question lingered: Will CJEU

75 Point 23 of the Guidance paper states: "The Commission will normally intervene only when the action in question has already prevented competition or is capable of preventing it, excluding competitors deemed to be equally effective as the dominant undertaking."

76 Points $40-47$ of the Guidance paper

77 Point 44 of the Guidance paper states: "Where the effective price is below AAC, as a general rule the rebate scheme is capable of foreclosing even equally efficient competitors. Where the effective price is between AAC and LRAIC, the Commission will investigate whether other factors point to the conclusion that entry or expansion even by equally efficient competitors is likely to be affected."

78 Point 43 of the Guidance paper

79 Point 23 of the Guidance paper

80 This analysis has its opponents as well, pointing to its deficiencies. For a summary of arguments see, Jones, Alison, Fidelity Rebates, a note submitted to Organisation for Economic Co-operation and Development Directorate for Financial and Enterprise Affairs, Competition Committee, DAF/COMP/ WD (2016) 62, 30 June 2016., available at:

http://www.oecd.org/officialdocuments/publicdisplaydocumentpdf/?cote=DAF/COMP/ WD(2016)62\&docLanguage=En] Accessed 23.03.2018, pp. 11-12 citing Krattenmaker, T. G., Salop, S. C., Anticompetitive Exclusion: Raising Rivals' Costs to Achieve Power Over Price, Yale Law Journal, 1986/96, pp. 209-293; Salop, S. C., Exclusionary Conduct, Effect on Consumers, and the Flawed Profit-Sacrifice Standard, Antitrust Law Journal, 2006/73, pp. 311-374. See also Wright, J. D., Simple but Wrong or Complex but More Accurate? The Case for an Exclusive Dealing-Based Approach to Evaluating Loyalty Discounts, Bates White 10th Annual Antitrust Conference, Washington, D.C., 3 June 2013, accessible at:

'https://www.ftc.gov/sites/default/files/documents/public_statements/simple-wrong-or-complex-more-accurate-case-exclusive-dealing-based-approach-evaluating-loyalty/130603bateswhite.pdf] Accessed 23.03.2018 
embrace the proposed effects-based analysis and thus transform soft into hard law? So far, the Commission had a rather comfortable position because all of the cases it dealt with related to facts that took place before the adoption of the Guidance paper. Consequently, the Commission was not obliged to apply its own criteria set in the Guidance paper (although it did so on a number of occasions). The same happened in Intel. The facts in Intel took place years before the Guidance paper was adopted, and thus, it came as no surprise that the Commission applied the traditional prima facie infringement rule and found that the rebates offered by Intel were by their very nature capable of restricting competition. ${ }^{81}$ Accordingly, the Commission stressed out that the assessment based on all the circumstances of the case and, in particular an AEC test, was not necessary in order to find the infringement of Article 102 of the TFEU. Having said that, the Commission did perform a thorough analysis of all the circumstances under the AEC test, which led it to conclude "that an as efficient competitor would have had to offer prices which would not have been viable and that, accordingly, the rebate scheme at issue was capable of having foreclosure effects on such a competitor." ${ }^{82}$ Although presented by the Commission as corroborative evidence, the analysis opened the door to a heated debate eventually leading to the overturning judgement by the CJEU in favour of the more economic approach to fidelity rebates. As will be seen below, this practically converted the Guidance paper from a Commission self-imposed soft-law document, into EU competition hard law. ${ }^{83}$

The Guidance paper is a very specific type of soft law instrument adopted by the Commission, inasmuch as it did much more than simply summarise the existing case law on Article 102 of the TFEU. Instead, the Guidance paper had the ambition to influence the interpretation of Article 102 and widen its scope. ${ }^{84}$ However, having in mind the institutional divide within the EU, the Commission did not have the authority to do so, as the CJEU is the only institution entrusted with the task to interpret EU law. In order to overcome this institutional boundary, the Commission came up with the document that is formally declared to serve the sole purpose of defining its enforcement priorities, an issue falling within its competence. ${ }^{85}$ The Guidance paper explicitly states that it is not intended to constitute a statement of law and is without prejudice to the interpretation given to

\footnotetext{
81 Commission decision - Intel, para 916

82 CJEU, Intel, EU:C:2017:632, para. 142; Commission Decision — Intel, paras. 925 and 1760

83 See Lamadrid, op. cit. note 65, p. 2

84 Ezrachi, Ariel, EU Competition Law, An Analytical Guide to the Leading Cases, $5^{\text {th }}$ ed., Hart Publishing, Oxford and Portland, Oregon, 2016, p. 211

85 GCEU, judgment of 18 September 1992, Automec Srlv Commission, T-24/90, EU:T:1992:97, para 77
} 
Article 102 by the CJEU.$^{86}$ However, many commentators would agree that Guidance paper is in effect substantive guidelines rising legitimate expectations in that regard. ${ }^{87}$ Welcoming this development, they hoped that the economic approach found in the Guidance paper "would serve as an inspiration to the EU Courts to change case-law" 88 to the effect that this approach becomes the substantive standard of assessment when determining illegality rather than a mere procedural standard of assessment when determining priority. As judgment in Intel shows, the high expectations and exercised pressure though public debate, delivered.

\subsection{The CGEU judgement}

In its judgment, the GCEU, dismissed in its entirety the action brought by Intel abiding by the traditional approach to fidelity rebates, making this s "significant victory" for the Commission. ${ }^{89}$ The heart of the GCEU decision was its classification of rebates into: 1) quantity rebates, ${ }^{90}$ presumed to be legal as they generally do not raise competition concerns, 2) exclusivity rebates, ${ }^{91}$ presumed to be illegal as they are anticompetitive by their very nature and, 3) "other rebates", ${ }^{22}$ necessitating the consideration of all circumstances of the case in order to determine if

86 Point 3 of the Guidance paper

87 See Lovdahl Gromsen, L., Why the European Commission's enforcement priorities on article 82 EC should be withdrawn, European Competition Law Review, 2010/31 (2), pp. 45-55

88 Wils, W. P. J., The Judgment of the EU General Court in Intel and the So-Called 'More Economic Approach' to Abuse of Dominance (September 19, 2014), World Competition: Law and Economics Review, 2014/37 (4), pp. 405-434, available at SSRN: [https://ssrn.com/abstract=2498407] Accessed 23.03.2018, citing Allan, B., Rule-making in the context of Article 102 TFEU, Competition Law Journal 2014, pp. 7 et seq. especially 20-21; Ibánez Colomo, P., Intel v Commission and the problem with wrong economic assumptions, Chillin' competition, 16 June 2014, [https://chillingcompetition. com/2014/06/16/intel-v-commission-and-the-problem-with-wrong-economic-assumptions/] Accessed 23.03.2018; Venit, J. S., Case T-286/09 Intel v Commission - The Judgement of the General Court: All steps Backward and no Steps Forwards, European Competition Journal 2014/10 (2), pp. 203-230

89 Cardoso Pereira, op. cit. note 38, p. 208

90 According to the GCEU, "quantity rebate systems ('quantity rebates') linked solely to the volume of purchases made from an undertaking occupying a dominant position are generally considered not to have the foreclosure effect prohibited by Article 82 EC. "GCEU, Intel, EU:T:2014:547, para. 75

91 According to the GCEU, "there are rebates the grant of which is conditional on the customer's obtaining all or most of its requirements from the undertaking in a dominant position." GCEU, Intel, EU:T:2014:547, para. 76

92 According to the GCEU, "there are other rebate systems where the grant of a financial incentive is not directly linked to a condition of exclusive or quasi-exclusive supply from the undertaking in a dominant position, but where the mechanism for granting the rebate may also have a fidelity-building effect ('rebates falling within the third category'). That category of rebates includes inter alia rebate systems depending on the attainment of individual sales objectives which do not constitute exclusivity rebates, since those systems do not contain any obligation to obtain all or a given proportion of supplies from the dominant undertaking.." GCEU, Intel, EU:T:2014:547, para. 78 
they are capable of restricting competition. Within this classification, the GCEU placed the rebate scheme offered by Intel into the category of exclusive rebates and, relying on the case law stemming from Hoffmann La Roche, it did not find necessary either to consider all the circumstances of the case to determine if the scheme was capable of restricting competition ${ }^{93}$ or to carry out the ACE test. ${ }^{94}$ The GCEU stated that when it comes to exclusivity rebates the capability to restrict competition can be assumed because, except for exceptional circumstances, such conduct lacks an economic justification. ${ }^{95}$ In addition, it observed that "the capability of tying customers to the undertaking in a dominant position is inherent in exclusivity rebates", ${ }^{96}$ adding that "a foreclosure effect occurs not only where access to the market is made impossible for competitors, but also where that access is made more difficult." ${ }^{\text {97 }}$ Finally, the GCEU stressed out the possibility of a dominant undertaking to rebut the presumption of abuse, which Intel failed to do. In fact, the GCEU stated that Intel did not bring forward any argument to that effect.

This approach to exclusive dealing is different from the approach taken by the CJEU in cases of exclusive dealing within the ambit or Article 101 of the TFEU. In the famous Delimitis ${ }^{98}$ judgment, exclusive dealing was found to be a conduct that may have beneficial effects on competition and thus it was necessary to assess its effects on the market in order to decide whether it infringed Article $101 .{ }^{99} \mathrm{In}$ other words, exclusive dealing under Article 101 is considered to be an infringement by effect while the same type of behaviour within the context of Article 102 is considered to be an infringement by object. This dichotomy has been criticised for inconsistency. ${ }^{100}$ The GCEU, however, argued that the more stringent approach to exclusive dealing under Article 102 is justified by the fact that it is precisely because of the very existence of a dominant position that the competition is already impaired. ${ }^{101}$ The GCEU continued by restating the famous principle underpinning the normative approach to dominant undertakings - the special responsibil-

\footnotetext{
93 GCEU, Intel, EU:T:2014:547, paras. 76-77

94 GCEU, Intel, EU:T:2014:547, para. 85

95 GCEU, Intel, EU:T:2014:547, paras. 76-77

96 GCEU, Intel, EU:T:2014:547, para. 86

97 GCEU, Intel, EU:T:2014:547, para. 88

98 CJEU, judgment of 28 February 1991, Stergios Delimitis v Henninger Bräu AG, C-234/89, EU:C:1991:91

99 CJEU, Delimitis, EU:C:1991:91, paras. 14-27

100 See Ibáñez Colomo, op. cit. note 88

101 GCEU, Intel, EU:T:2014:547, para. 89
} 
ity of a dominant undertaking not to impair genuine undistorted competition ${ }^{102}$ and held that "exclusive supply conditions in respect of a substantial proportion of purchases by a customer constitute an unacceptable obstacle to access to the market." 103

Rather convincingly, this differentiation has been emphasised in support of the GCEU judgement by Wils who reminds that ,the nature and effects of what may look like the same practice can be very different depending on whether the undertaking adopting the practice is dominant or not. Moreover, by providing for Article 102 [of the] TFEU in addition to Article 101 [of the] TFEU, the EU Treaties have chosen to treat dominant undertakings differently from non-dominant undertakings." ${ }^{104}$ These fundamental principles of EU competition law cannot be overestimated. It is the economic rationale and the legal aim behind the wording of 102 - the preservation of undistorted competition - that should not be lost out of sight. And it is exactly the same as the economic rationale and legal aim that underlies the presumption of illegality of exclusivity rebates, as explained by the GCEU in Intel. ${ }^{105}$ As Whish rightly points out, "it is not clear why the differentiation between the treatment of exclusive dealing under Article 101 and 102 [of the] TFEU should be regarded as wrong in principle - to apply a stricter standard to exclusivity when a firm is dominant." 106 It is precisely because of the dominant undertaking that the competition is already impaired. Moreover, as recognised by the CJEU, such undertakings should not carry out any conduct which could affect competition on the market. ${ }^{107}$ This also includes the conduct that would otherwise be legal, i.e. if undertaken by a non-dominant undertaking, such as refusal of supply.

It is not only the more stringent approach to exclusive dealing under Article 102 of the TFEU that was under criticism by the commentators. The very classifi-

102 The most famous and cited quote from Hoffmann la Roche relates to defining the concept of abuse: "The concept of abuse is an objective concept relating to the behaviour of an undertaking in a dominant position which is such as to influence the structure of a market where, as a result of the very presence of the undertaking in question, the degree of competition is weakened and which, through recourse to methods different from those which condition normal competition in products or services on the basis of the transactions of commercial operators, has the effect of hindering the maintenance of the degree of competition still existing in the market or the growth of that competition. "CJEU, Hoffmann la Roche, EU:C:1979:36, para 91

103 GCEU, Intel, EU:T:2014:547, para. 90

104 Wils, op. cit. note 88, p. 24

105 Ibid. p. 23

106 Whish, R., Intel v Commission: Keep Calm and Carry on!, Journal of European Competition Law \& Practice, 2015/6 (1), pp. 1-2

107 CJEU, Hoffmann-La Roche, EU:C:1979:36 para 91; CJEU, Intel, EU:C:2017:632, para. 135 
cation of rebates as done by the GCEU has been criticised by many, ${ }^{108}$ including the Advocate General Wahl, ${ }^{109}$ for being overly formalistic, artificial and thus arbitrary, ${ }^{110}$ because boundaries between those categories are difficult to define. ${ }^{111}$ The critics are particularly pointing to the subcategory of rebates - the exclusivity rebates, which was at the centre of the GCEU judgement. ${ }^{112}$ However, as presented by the GCEU, such categorisation appears to be nothing more than the systematisation of the previous case law. While the first category - quantity rebates and their presumption of legality, restates the findings of the CJEU in the case Michelin II ${ }^{113}$ the second category of exclusivity rebates and the accompanying presumption of illegality rest on judgments in Hoffman la Roche $e^{114}$ and more recently Tomra. ${ }^{15}$ The third category of "other rebates" relates to factual in which "the grant of a financial incentive is not directly linked to a condition of exclusive or quasi-exclusive supply from the undertaking in a dominant position, but where the mechanism for granting the rebate may also have a fidelity-building effect", as was the case in Michelin $I^{116}$ and British Airways. ${ }^{117}$

Not everyone agreed with this reading of the existent case law of EU Courts. This fact alone indicates that there is not enough consistency or clarity in the treatment

108 See Colangelo, G., Maggiolino, M., Intel and the Rebirth of the Economic Approach to EU Competition Law (January 18, 2018), International Review of Intellectual Property and Competition Law - IIC, 2018/49, available at SSRN: [http://dx.doi.org/10.2139/ssrn.3104850] Accessed 23.03.2018, p. 6; Petit, N., The Advocate General's Opinion in Intel v Commission: Eight Points of Common Sense for Consideration by the CJEU (November 24, 2016), Concurrences Review, No. 1, available at SSRN: [https:// ssrn.com/abstract=2875422] Accessed 23.03.2018, p. 3-5; Geradin, op. cit. note 66, pp. 599-600

Stepping Stone to a Fresh Legal Framework for the Analysis of Rebates Under EU Competition Law (Janu-
ary 4, 2017), Concurrences Review, 2017/1, available at SSRN: [https://ssrn.com/abstract=2893792]
Accessed 23.03.2018, p. 4

111 This difficulty is well demonstrated in CJEU, Post Danmark II, EU:C:2015:651

112 In his opinion in Intel, para 84, the Advocate General Wahl criticised the GCEU for having „distinguished one sub-type of loyalty rebate, which it termed 'exclusivity rebates', from other types of rebates that induce loyalty. In doing so, it created a 'super category' of rebates for which consideration of all the circumstances is not required in order to conclude that the impugned conduct amounts to an abuse of dominance contrary to Article 102 [of the] TFEU. More importantly, the abusiveness of such rebates is assumed in the abstract, based purely on their form."

113 GCEU, judgment of 30 September 2003, Manufacture française des pneumatiques Michelin v Commission of the European Communities (Michelin II), T-203/01, EU:T:2003:250, para. 58

114 CJEU, Hoffmann-La Roche, EU:C:1979:36

115 GCEU, judgment of 9 September 2010, Tomra Systems ASA and Others $v$ European Commission, T-155/06, EU:T:2010:370, paras. 72 and 209-210

116 CJEU, judgment of 9 November 1983, NV Nederlandsche Banden Industrie Michelin $v$ Commission (Michelin I). 322/81, EU:C:1983:313

117 CJEU, British Airways, EU:C:2007:166 
of specific types of abuse of dominant by the EU courts. An attempt to categorise in a precise and clear manner existent case law is welcome and important from the perspective of legal certainty and intelligibility of rules applied, ${ }^{118}$ particularly considering that such rules are not void of economic rationale. ${ }^{19}$ Legal rules are meant to be as unambiguous and straightforward as possible and should be applicable at the lowest cost encompassing the majority of situations. ${ }^{120}$ This is exactly what a rule-based approach does. Under assumption that in majority of situations exclusive dealing by a dominant undertaking distorts competition, a presumption of illegality makes perfect sense from the perspective of law enforcement. The approach to infringements by object have been very plastically described by Advocate General Kokott in T-mobile under Article 101. Advocate General Kokott used the analogy of drunk drivers: "In most legal systems, a person who drives a vehicle when significantly under the influence of alcohol or drugs is liable to a criminal or administrative penalty, wholly irrespective of whether, in fact, he endangered another road user or was even responsible for an accident. In the same vein, undertakings infringe European competition law and may be subject to a fine if they engage in concerted practices with an anti-competitive object; whether in an individual case, in fact, particular market participants or the general public suffer harm is irrelevant." ${ }^{121}$ Arguments stressing that fidelity rebates may have mixed effects on competition, and thus that the assumption of illegality is "not just disproportionately harsh; it is outright inadequate" 122 fail to recognise the important enforcement-related advantages of the presumption of illegality. As long as this presumption is rebuttable, there is no risk for dominant undertakings being fined for an objectively justified conduct.

The CJEU was not convinced of these arguments, and instead it ruled in favour of the "more economic approach" to fidelity rebates and overturned the existent line of case law.

118 Wils, op. cit. note 88, p. 23; Wardhaugh, B., Intel, Consequentialist Goals and the Certainty of Rules: The Same Old Song and Dance, My Friend, Competition Law Review, 2016/11 (2), pp. 215-238: "While the Commission's desire to promote consumer welfare may be laudable, the achievement of the goal needs to be done through a system which provides the needed ex ante certainty for decisions to be predictably made in a workable legal system."

119 See Wils, op. cit. note 88, p. 31

120 Ibid. pp. 23-26: "When choosing between one or the other interpretation of Article 102 of the TFEU (for instance, between the existing EU case-law and the so-called 'more economic approach'), all relevant effects of the choice of interpretation should be taken into account, including enforcement costs, and the degree of legal uncertainty and the corresponding allocation of risk." p. 26

121 CJEU, judgment of of 4 June 2009, T-Mobile Netherlands BV, KPN Mobile NV, Orange Nederland $N V$ and Vodafone Libertel NVv Raad van bestuur van de Nederlandse Mededingingsautoriteit, C-8/08, EU:C:2009:110, para. 47

122 Marco Colino, op. cit. note 110, p. 4 


\subsection{The CJEU judgement}

The CJEU quashed the judgment of the GCEU on the argument that, because the AEC test played an important role in the Commission's findings, the GCEU was required to examine all of Intel's arguments concerning that test. ${ }^{123}$ It was an error in law, according to the CJEU, that in examining the circumstances of the case, even if only for the purpose of completeness, the GCEU attached importance to AEC test performed by the Commission while refusing to take into consideration the arguments of Intel pointing to the incorrectness of the performance if this test. ${ }^{124}$ The CJEU's logic seems to suggest that if such arguments were used by the Commission, then counter arguments must be examined as well.

The CJEU employed an essentially procedural line of reasoning to refute a substantive approach to abuse of dominance. However, had this been the only point in its judgment in Intel, it would have implied that in the absence of such analysis by the Commission, the GCEU would not be under such duty either. Accordingly, the discretion on whether or not to treat rebates as rule-based infringements of Article 102 would sit with the Commission. Given that this approach would be unacceptable in principle, the CJEU put forward clear rules on the Commission's duty to perform AEC test and analyse other circumstances of the case in order to prove the capability of foreclosure. It is with this part of the judgment that CJEU overturned the Hoffmann la Roche line of reasoning.

The CJEU commenced by restating how dominant undertakings have a special responsibility not to impair undistorted competition on the internal market. It then repeated the traditional approach to fidelity rebates from Hofmann la Roche only to continue by stating that case-law should be further clarified. ${ }^{125}$ The clarification of the CJEU relates to situations when a dominant undertaking during the administrative procedure, on the basis of supporting evidence, submits that "its conduct was not capable of restricting competition and in particular, of producing the alleged foreclosure effects." ${ }^{126}$ In such situations, according to the CJEU, the Commission is required to analyse all circumstances of the case including "the extent of the undertaking's dominant position on the relevant market and, secondly, the share of the market covered by the challenged practice, as well as the conditions and arrangements for granting the rebates in question, their duration and their amount; it is also required to assess the possible existence of a strategy

\footnotetext{
123 CJEU, Intel, EU:C:2017:632, para. 141

124 See CJEU, Intel, EU:C:2017:632, para. 147

125 CJEU, Intel, EU:C:2017:632, para. 138. Here we would have to agree with Lamadrid, op. cit. note 65, that this was just a euphemism for an overturning judgement

126 CJEU, Intel, EU:C:2017:632, para. 138
} 
aiming to exclude competitors that are at least as efficient as the dominant undertaking from the market." ${ }^{27}$ In addition, dominant undertaking is allowed to claim efficiencies or objective justification for its conduct. According to the CJEU, "balancing of the favourable and unfavourable effects of the practice in question on competition can be carried out in the Commission's decision only after an analysis of the intrinsic capacity of that practice to foreclose competitors which are at least as efficient as the dominant undertaking." 128

This analysis is clearly directed to the Commission and the administrative procedure. The Commission is required to perform full analysis only when a dominant undertaking submits that its conduct is not capable of distorting competition. With such position the CJEU does retain the presumption of illegality, but this appears rather formalistic as the dominant undertaking will always submit that its conduct was not capable of distorting competition. Then it is back to the Commission to prove anticompetitive effect based on all evidence including the AEC test. Then again, the burden of proof switches back to the dominant undertaking to prove the existence of an objective justification of efficiencies. These are rules of the game, the procedural framework supporting the findings of the CJEU in Post Danmark.

Several issues emerge from the Intel judgment. The first one relates to proving the capability of foreclosure effects. What does it mean? Much has been written about the standard of proof as the EU Courts have used interchangeably the terms such as "capability", "likelihood", "probability", and "potential". ${ }^{129}$ In Intel, however, the CJEU uses only the term "capability" to define both the standard of proof by the dominant undertaking and the Commission. Ibáñez Colomo rightly observes that there are two possible interpretations of this standard. The first interpretation could be that "dominant firms would have to satisfy the same level of evidence that the Commission has to meet to discharge its legal burden of proof." The sec-

127 CJEU, Intel, EU:C:2017:632, para. 139

128 CJEU, Intel, EU:C:2017:632, para. 140

129 On a difference between capability and likelihood see See Ibáñez Colomo, op. cit. note 88; cit.; Ibáñez Colomo, The future of Article 102 TFEU..., cit., pp. 14-20. For a different view see Kadar. op. cit. note 54: "It is clear that, from a strictly linguistic perspective, the fact that a conditional rebate scheme is likely or probable to produce anticompetitive effects is different from the fact that that scheme is 'only' capable of doing so, or that it tends to do so, or that it is potentially anticompetitive. Nevertheless, this apparent inconsistency can be reconciled if one leaves aside arguments 'based on a purely semantic distinction' (Opinion of AG Kokott in British Airways, para. 76) and acknowledges that the Courts use these terms as synonyms to identify a middle ground between purely hypothetical effects and actual effects. This middle ground, which can be perhaps best captured with the expression 'potential anticompetitive effects," can be considered as the point at which a given conduct by a dominant undertaking becomes abusive." 
ond interpretation, based on the principle of presumption of innocence and the principle that the burden of establishing an infringement lies with the authority or claimant, would imply that "it would be sufficient for the dominant firm to raise doubts about the capability of the practice to restrict competition." ${ }^{130} \mathrm{Hav}$ ing in mind that in Intel the CJEU actually abandoned the rule-based approach to rebates, we would have to go for the second opinion.

Another important issue dealt with by the CJEU concerns dominant undertaking's possibility to use the efficiency defence within the ambit of Article 102 of the TFEU. The wording of Article 102 does not envisage the possibility of exceptions based on efficiencies. To the contrary, Article 101(3) explicitly provides for this possibility. The difference in wordings derives from the assumption that where a dominant undertaking is present on the market stricter rules apply because its very presence impairs competition. This is the reason why within the ambit of Article 102 dominant undertakings could have only relied on objective justification. In 2009, when Guidance paper was adopted, the gap created with the case law existing at the time, related to efficiencies as well. Namely, the Guidance paper explicitly introduced the possibility to use efficiency arguments to offset the finding of abuse of dominance contrary to the then case law. Subsequently, in a sequence of cases related to abusive pricing practices, the CJEU endorsed this approach, confirmed in Post Danmark $I^{131}$ and now explicitly in Intel. As a result, efficiency gains are now a matter of public policy underlying Article 102, ${ }^{132}$ and effect-based analysis is applicable across the range of abuses. Colangelo and Maggiolino wrote that without even being mentioned in the CJEU judgment, the Guidance papers is the "real moral winner of the Intel affair." 133 For all we have stated above, it seems that the real winners in Intel are dominant undertakings. The question remains as to whether this was a win-win situation or perhaps there will be a losing party.

130 Ibáñez Colomo, The future of Article 102 TFEU..., cit., pp. 23-24

131 To succeed with an efficiency defence in the context of unilateral conduct, "it is for the dominant undertaking to show that the efficiency gains likely to result from the conduct under consideration counteract any likely negative effects on competition and consumer welfare in the affected markets, that those gains have been, or are likely to be, brought about as a result of that conduct, that such conduct is necessary for the achievement of those gains in efficiency and that it does not eliminate effective competition, by removing all or most existing sources of actual or potential competition." CJEU, (Post Danmark I), EU:C:2012:172, para. 42

132 Petit, op. cit. note 3, p.15

133 Colangelo,Maggiolino, op. cit. note 108, p. 12 


\section{CONCLUSION}

The above analysis demonstrates that there is a lot to tell about Intel. Although this case has initially provoked the interest of the public due to the then highest fine ordered by the Commission, it has nevertheless stirred to academic and professional waters much more concerning its legal implications.

On the scope of application of the EU competition law and the associated Commission jurisdiction to decide the antitrust cases against persons and activities located outside the EU, the CJEU judgment in Intel finally settles the long-lasting dilemma of whether the effects doctrine is part of the EU competition law. With the explicit confirmation of the "qualified effects" doctrine, the triangle of alternative legal bases has been completed. This "extraterritoriality triangle" now should capture all anti-competition situations, which might be detrimental to the competition structure on the internal market.

Regarding the exclusive dealings and fidelity rebates under Article 102, the declared clarification in this judgment in fact amounts to analytical shift, embracing the effect-based approach to these types of dealings. This will bring about more economic analysis in the process of assessment of the illegality of conduct of dominant undertaking concerned, but at the same time it will enable more room for the undertaking to justify the disputed conduct. The Intel judgment is definitely a positive development in this sense as this approach is more aligned with the Commission practice described already in the 2009 in the Guidance paper.

\section{REFERENCES}

\section{BOOKS AND ARTICLES}

1. Akbar, Y., The Extraterritorial Dimension of US and EU Competition Law: A Threat to the Multilateral System?, Australian Journal of International Affairs, 1999/53(1), pp. 113-125

2. Alford, R. P., The Extraterritorial Application of Antitrust Laws: The United States and European Community Approaches, Virginia Journal of International Law, 1992/33 (1), pp. 1-50

3. Allan, B., Rule-making in the context of Article 102 TFEU, Competition Law Journal, 2014/13

4. Basedow, J., Competition policy in a globalized economy: from extraterritorial application to harmonization, in: Neumann, M., Weigand J. (eds.), The International Handbook of Competition, Edward Elgar, 2004, pp. 321-338

5. Behrens, P., The extraterritorial reach of EU competition law revisited - The "effects doctrine" before the ECJ, Discussion paper 3/2016, Europa-Kolleg Hamburg Institute for European Integration, 2016, [https:/www.econstor.eu/bitstream/10419/148068/1/87238506X.pdf] Accessed 23.03.2018 
6. Braakman, A. J., Brexit and its Consequences for Containerised Liner Shipping Services, The Journal of International Maritime Law, 2017/23 (4), pp. 254-265

7. Cannon, R., Laker Airways and the Courts: A New Method of Blocking the Extraterritorial Application of U. S. Antitrust Laws, Journal of Comparative Business and Capital Market Law, 1985/7, pp. 63-87

8. Cardoso Pereira, J., Intel and the Abuse of Dominant Position: the General Court Upholds the Highest Fine Imposed on a Single Company for a Competition Law Infringement, European Law Reporter, 2017/7-8, pp. 204-209

9. Colangelo, G., Maggiolino, M., Intel and the Rebirth of the Economic Approach to EU Competition Law (January 18, 2018), International Review of Intellectual Property and Competition Law - IIC, 2018/49, available at SSRN:

[http://dx.doi.org/10.2139/ssrn.3104850] Accessed 23.03.2018

10. Ezrachi, A., EU Competition Law, An Analytical Guide to the Leading Cases, 5th ed., Hart Publishing, 2016

11. Frenz, W., Handbook of EU Competition Law, Springer, 2016

12. Geradin, D., Loyalty Rebates after Intel: Time for the European Court of Justice to Overrule Hoffman-La Roche, Journal of Competition Law \& Economics, 2015/11 (3), pp. 579-615

13. Gradine, D., Reyesen, M., Henry, D., Extraterritoriality, Comity and Cooperation in EU Competition Law, in: Guzmán, A. T. (ed.), Cooperation, Comity, and Competition Policy, Oxford University Press, 2011, pp. 21-44

14. Griffin, J., Foreign Governmental Reactions to US Assertions of Extraterritorial Jurisdiction, George Mason Law Review, 1998/6 (3), pp. 505-524

15. Ibáńez Colomo, P., Editorial: The divide between restrictions by object and effect: why we discuss it and why it matters, Competition Law Review, 2016/1 (2), pp. 173-180

16. Ibáñez Colomo, P., Intel and Article 102 TFEU Case Law: Making Sense of a Perpetual Controversy (November 26, 2014), LSE Legal Studies Working Paper No. 29/2014, available at SSRN:

[https://ssrn.com/abstract=2530878] or [http://dx.doi.org/10.2139/ssrn.2530878] Accessed 23.03.2018

17. Ibáñez Colomo, P., Intel $v$ Commission and the problem with wrong economic assumptions, Chillin' competition, 16 June 2014, [https://chillingcompetition.com/2014/06/16/intel-v-commission-and-the-problem-withwrong-economic-assumptions/] Accessed 23.03.2018

18. Ibáñez Colomo, P., More on Intel: some thoughts after the IBA Conference in Florence, Chillin` competition, 12 September 2017, available at:

[https://chillingcompetition.com/2017/09/12/more-on-intel-some-thoughts-after-the-ibaconference-in-florence/] Accessed 23.03.2018

19. Joanne. S., The new EU “extraterritoriality", Common Market Law Review, 2014/ 51 (5), pp. 1343-1380

20. Kadar, M., The meaning of "Anticompetitive Effects" Under Article 102 TFEU, CPI Antitrust Chronicle, March 2016 (1), available at:

[https://www.competitionpolicyinternational.com/wp-content/uploads/2016/03/TheMeaning-of-Anticompetitive-Effects.pdf] Accessed 23.03.2018 
21. Katzorowska, A., European Union Law, Routledge, 2013

22. Krattenmaker, T. G., Salop, S. C., Anticompetitive Exclusion: Raising Rivals' Costs to Achieve Power Over Price, Yale Law Journal, 1986/96, pp. 209-293

23. Lamadrid, A., More questions (and some answers) on, and beyond, Intel (C-413/14P), Chillin competition, 6 September 2017 , available at:

[https://chillingcompetition.com/2017/09/06/more-questions-and-some-answers-on-andbeyond-intel-c-41314-p/] Accessed 23.03.2018

24. Lovdahl Gromsen, L., Why the European Commission's enforcement priorities on article 82 EC should be withdrawn, European Competition Law Review, 2010/31 (2), pp. 45-55

25. Marco Colino, S., All Eyes on Intel: A Stepping Stone to a Fresh Legal Framework for the Analysis of Rebates Under EU Competition Law (January 4, 2017), Concurrences Review, 2017/1, available at SSRN: [https://ssrn.com/abstract=2893792] Accessed 23.03.2018

26. Petit, N., The Advocate General's Opinion in Intel v Commission: Eight Points of Common Sense for Consideration by the CJEU (November 24, 2016), Concurrences Review, No. 1, available at SSRN: [https://ssrn.com/abstract=2875422] Accessed 23.03.2018

27. Petit, N., The Judgment of the EU Court of Justice in Intel and the Rule of Reason in Abuse of Dominance Cases (December 12, 2017), European Law Review, October 2018 (forthcoming), available at SSRN: [https://ssrn.com/abstract=3086402] or [http://dx.doi.org/10.2139/ ssrn.308640219] Accessed 23.03.2018

28. Robertson, A., Demetriou, M., "But that was another country...": The Extra-Territorial Application of the US Antitrust Laws in the US Supreme Court, International and Comparative Law Quarterly, 1994/43, pp. 417-425

29. Salop, S. C., Exclusionary Conduct, Effect on Consumers, and the Flawed Profit-Sacrifice, Standard Antitrust Law Journal, 2006/73, pp. 311-374

30. Venit, J. S., Case T-286/09 Intel v Commission - The Judgement of the General Court: All steps Backward and no Steps Forwards, European Competition Journal, 2014/10 (2), pp. 203-230

31. Wagner-von Papp, F., Competition Law in EU Free Trade Cooperation Agreements (and What the UK Can Expect After Brexit), in: Bungenberg M., et al. (eds.), European Yearbook of International Economic Law, Springer, 2017, pp. 301-360

32. Wardhaugh, B., Intel, Consequentialist Goals and the Certainty of Rules: The Same Old Song and Dance, My Friend, Competition Law Review, 2016/11 (2), pp. 215-238

33. Whish, R., Bailey, D., Competition Law, 7th ed., Oxford University Press, 2012

34. Whish, R., Intel $v$ Commission: Keep Calm and Carry on!, Journal of European Competition Law \& Practice, 2015/6 ), pp. 1-2

35. Wils, W. P. J., The Judgment of the EU General Court in Intel and the So-Called 'More Economic Approach' to Abuse of Dominance (September 19, 2014), World Competition: Law and Economics Review, 2014/37 (4), pp. 405-434, available at SSRN: [https://ssrn.com/ abstract=2498407] Accessed 23.03.2018

36. Wright, J. D., Simple but Wrong or Complex but More Accurate? The Case for an Exclusive Dealing-Based Approach to Evaluating Loyalty Discounts, Bates White 10th Annual Antitrust Conference, Washington, D.C., 3 June 2013, accessible at: 
[https://www.ftc.gov/sites/default/files/documents/public_statements/simple-wrong-or-complex-more-accurate-case-exclusive-dealing-based-approach-evaluating-loyalty/130603bateswhite.pdf] Accessed 23.03.2018

\section{CASE LAW}

1. CJEU, judgment of 14 July 1972, Imperial Chemical Industries Ltd. $v$ Commission of the European Communities, case 48-69, EU:C:1972:70

2. CJEU, judgment of 21 February 1973, Europemballage Corporation and Continental Can Company Inc. $v$ Commission of the European Communities, case 6-72, EU:C:1973:22

3. CJEU, judgment of 6 March 1974, Istituto Chemioterapico Italiano S.p.A. and Commercial Solvents Corporation $v$ Commission of the European Communities, joined cases 6 and 7-73., EU:C:1974:18

4. CJEU, judgment of 16 December 1975, Coöperatieve Vereniging "Suiker Unie" UA and others $v$ Commission, C-40/73 etc., EU:C:1975:174

5. CJEU, judgment of 13 February 1979, Hoffmann-La Roche \& Co. AGv Commission of the European Communities, C-85/76 EU:C:1979:36

6. CJEU, judgment of 9 November 1983, NV Nederlandsche Banden Industrie Michelin v Commission (Michelin I), case 322/81, EU:C:1983:313

7. CJEU, judgment of 27 September 1988, Ahlström Osakeyhtiö and others $v$ Commission of the European Communities and other, joined cases C-89/85, C-104/85, C-114/85, C-116/85, C-117/85 and C-125/85 to C-129/85, EU:C:1988:447

8. CJEU, judgment of 28 February 1991, Stergios Delimitis v Henninger Bräu AG, C-234/89, EU:C:1991:91

9. GCEU, judgment of 18 September 1992, Automec Srlv Commission, T-24/90, EU:T:1992:97

10. CGEU, judgment of the of 25 March 1999, Gencor Ltd $v$ Commission of the European Communities, T-102/96, EU:T:1999:65

11. GCEU, judgment of 30 September 2003, Manufacture française des pneumatiques Michelin v Commission of the European Communities (Michelin II), T-203/01, EU:T:2003:250, para. 58

12. CJEU, judgment of 15 March 2007, British Airways plc $v$ Commission of the European Communities, C-95/04 P EU:C:2007:166

13. CJEU, judgment of of 4 June 2009, T-Mobile Netherlands BV, KPN Mobile NV, Orange Nederland NV and Vodafone Libertel NVv Raad van bestuur van de Nederlandse Mededingingsautoriteit, C-8/08, EU:C:2009:110

14. GCEU, judgment of 9 September 2010, Tomra Systems ASA and Others $v$ European Commission, T-155/06, EU:T:2010:370, paras. 72 and 209-210

15. CJEU, judgment of 14 October 2010, Deutsche Telekom AG v European Commission, C-280/08 P, EU:C:2010:603

16. CJEU, judgment of 17 February 2011, Konkurrensverket v TeliaSonera Sverige AB, C-52/09, EU:C:2011:83

17. CJEU, judgment of 27 March 2012, Post Danmark A/S v Konkurrencerådet (Post Danmark I), $C-209 / 10, \mathrm{EU}: \mathrm{C}: 2012: 172$ 
18. GCEU, judgment of 12 June 2014, Intel Corp. $v$ European Commission, T-286/09, EU:T:2014:547

19. CJEU, judgment of 10 July 2014, Telefónica SA and Telefónica de España SAU v European Commission, C-295/12 P, EU:C:2014:2062

20. CJEU, judgment of 6 October 2015, Post Danmark A/S v Konkurrencerådet. (Post Danmark II), C-23/14 EU:C:2015:651

21. CJEU, judgment of 6 September 2017, Intel Corp. v European Commission, C-413/14 P, EU:C:2017:632

22. United States v. Alcoa, 148 F.2d 416 (2d Cir. 1945)

\section{AG OPINIONS}

1. Opinion of Advocate General Mayras of 2 May 1972, Imperial Chemical Industries Ltd. $v$ Commission of the European Communities, joined cases 48-69 - 57-69, EU:C:1972:32

2. Opinion of Advocate General Damon of 7 June 1992, Ahlström Osakeyhtiö et al. V. Commission, joined cases C-89/85, EU:C:1988:258

3. Opinion of the Advocate General Wahl of 20 October 2016, Intel Corp. v European Commission, C-413/14 P, EU:C:2016:788, para. 294

\section{COMMISSION DECISIONS}

1. 64/233/CEE: Décision de la Commission, du 11 mars 1964, relative à une demande d'attestation négative présentée conformément à l'article 2 du règlement no 17 du Conseil (IV/A-00061 - Grosfillex-Fillistorf), OJ 58, 9.4.1964, pp. 915-916

2. 69/243/CEE: Décision de la Commission, du 24 juillet 1969, relative à une procédure au titre de l'article 85 du traité C.E.E. (IV/26.267 - Matières colorantes), OJ L 195, 7.8.1969, pp.11-17

3. 64/233/CEE: Décision de la Commission, du 11 mars 1964, relative à une demande d'attestation négative présentée conformément à l'article 2 du règlement no 17 du Conseil (IV/A00061 - Grosfillex-Fillistorf), OJ 58, 9.4.1964, pp. 915-916

4. 89/190/EEC: Commission Decision of 21 December 1988 relating to a proceeding pursuant to Article 85 of the EEC Treaty (IV/31.865, PVC), OJ L 74, 17.3.1989, pp. 1-20

5. 89/191/EEC: Commission Decision of 21 December 1988 relating to a proceeding pursuant to Article 85 of the EEC Treaty (IV/31.866, LdPE), OJ L 74, 17.3.1989, pp. 21-44

6. 2006/897/EC: Commission Decision of 19 January 2005 relating to a proceeding under Article 81 of the EC Treaty and Article 53 of the EEA Agreement against Akzo Nobel NV and others, OJ L 353, 13.12.2006, pp. 12-15

7. Commission Decision C(2009) 3726 final of 13 May 2009 in case COMP/C-3/37.990 Intel 


\section{LEGAL INSTRUMENTS}

1. Council Regulation (EEC) No 4064/89 of 21 December 1989 on the control of concentrations between undertakings, OJ L 395, 30.12.1989, pp. 1-12

2. Council Regulation (EC) No 139/2004 of 20 January 2004 on the control of concentrations between undertakings (the EC Merger Regulation), OJ L 24, 29.1.2004, pp. 1-22

3. Regulation (EU) No 600/2014 of the European Parliament and of the Council of 15 May 2014 on markets in financial instruments and amending Regulation (EU) No 648/2012, OJ L 173, 12.6.2014, pp. 84-148

4. Regulation (EU) No 648/2012 of the European Parliament and of the Council of 4 July 2012 on OTC derivatives, central counterparties and trade repositories, OJ L 201, 27.7.2012, pp. $1-59$

5. Treaty on the functioning of the European Union, OJ C 326, 26.10.2012, pp. 47-390 (consolidated version)

\section{OTHER DOCUMENTS}

1. Comments on the public consultation on discussion paper on the application of Article 82 to exclusionary abuses (March 2006),

[http://ec.europa.eu/competition/antitrust/art82/contributions.html] Accessed 23.03.2018

2. Communication from the Commission - Guidance on the Commission's enforcement priorities in applying Article 82 of the EC Treaty to abusive exclusionary conduct by dominant undertakings, OJ C 45, 24.2.2009, pp. 7-20

3. DG Competition discussion paper on the application of Article 82 of the Treaty to exclusionary abuses, Brussels, December 2005, [http://ec.europa.eu/competition/antitrust/art82/discpaper2005.pdf] Accessed 23.03.2018

4. Jones, A., Fidelity Rebates, a note submitted to Organisation for Economic Co-operation and Development Directorate for Financial and Enterprise Affairs, Competition Committee, DAF/ COMP/WD (2016) 62, 30 June 2016., available at:

[http://www.oecd.org/officialdocuments/publicdisplaydocumentpdf/?cote=DAF/COMP/ WD(2016)62\&docLanguage=En] Accessed 23.03.2018

5. Report by the EAGCP, An economic approach to Article 82, July 2005 [http://ec.europa.eu/ dgs/competition/economist/eagcp_july_21_05.pdf] Accessed 23.03.2018

6. Working Party No. 3 on Co-operation and Enforcement, Roundtable on cartel jurisdiction issues, including the effects doctrine, 21.10.2008, available at [http://ec.europa.eu/competition/international/multilateral/oecd_submissions.html] Accessed 23.03.2018 